\title{
Nutritional value of high fiber co-products from the copra, palm kernel, and rice industries in diets fed to pigs
}

\author{
Hans Henrik Stein ${ }^{1 *}$, Gloria Amparo Casas ${ }^{1,2}$, Jerubella Jerusalem Abelilla', Yanhong Liu ${ }^{3}$ and \\ Rommel Casilda Sulabo ${ }^{4}$
}

\begin{abstract}
High fiber co-products from the copra and palm kernel industries are by-products of the production of coconut oil and palm kernel oil. The co-products include copra meal, copra expellers, palm kernel meal, and palm kernel expellers. All 4 ingredients are very high in fiber and the energy value is relatively low when fed to pigs. The protein concentration is between 14 and $22 \%$ and the protein has a low biological value and a very high Arg:Lys ratio. Digestibility of most amino acids is less than in soybean meal but close to that in corn. However, the digestibility of Lys is sometimes low due to Maillard reactions that are initiated due to overheating during drying. Copra and palm kernel ingredients contain 0.5 to $0.6 \%$ P. Most of the P in palm kernel meal and palm kernel expellers is bound to phytate, but in copra products less than one third of the P is bound to phytate. The digestibility of $\mathrm{P}$ is, therefore, greater in copra meal and copra expellers than in palm kernel ingredients. Inclusion of copra meal should be less than $15 \%$ in diets fed to weanling pigs and less than $25 \%$ in diets for growing-finishing pigs. Palm kernel meal may be included by $15 \%$ in diets for weanling pigs and $25 \%$ in diets for growing and finishing pigs.

Rice bran contains the pericarp and aleurone layers of brown rice that is removed before polished rice is produced. Rice bran contains approximately $25 \%$ neutral detergent fiber and 25 to $30 \%$ starch. Rice bran has a greater concentration of P than most other plant ingredients, but 75 to $90 \%$ of the $\mathrm{P}$ is bound in phytate. Inclusion of microbial phytase in the diets is, therefore, necessary if rice bran is used. Rice bran may contain 15 to $24 \%$ fat, but it may also have been defatted in which case the fat concentration is less than $5 \%$. Concentrations of digestible energy (DE) and metabolizable energy (ME) are slightly less in full fat rice bran than in corn, but defatted rice bran contains less than $75 \%$ of the DE and ME in corn. The concentration of crude protein is 15 to $18 \%$ in rice bran and the protein has a high biological value and most amino acids are well digested by pigs. Inclusion of rice bran in diets fed to pigs has yielded variable results and based on current research it is recommended that inclusion levels are less than 25 to $30 \%$ in diets for growing-finishing pigs, and less than $20 \%$ in diets for weanling pigs. However, there is a need for additional research to determine the inclusion rates that may be used for both full fat and defatted rice bran.
\end{abstract}

Keywords: Copra expellers, Copra meal, Palm kernel expellers, Palm kernel meal, Rice bran

\footnotetext{
* Correspondence: hstein@illinois.edu

'Department of Animal Science, University of Illinois, Urbana 61801, USA

Full list of author information is available at the end of the article
} 


\section{Background}

With the increased global production of livestock, dairy, and poultry, the demand for feed is also increasing and co-products from the tropical food industries are increasingly used in diets fed to pigs. These co-products include copra meal and copra expellers, palm kernel meal and palm kernel expellers, and rice bran. Global production of palm kernel and copra products is relatively modest compared with the production of soybean meal and canola meal [1] and availability of these ingredients is often geographically dependent. However, in some areas, these ingredients are the most abundant and least expensive sources of energy and amino acids (AA) that are available to the local swine industry [2] and it is, therefore, important that information about the nutritional value of each ingredient is available. It is also recognized that copra-, palm kernel-, and rice co-products have certain specific attributes including AA profile, fatty acid profile, and composition of fiber that are unique to these ingredients and special attention to these attributes is needed. The objective of this review, therefore, is to provide information about the composition and recommended use of copra- and palm kernel products and of defatted and full fat rice bran when fed to pigs. The review is primarily based on literature published in peer-reviewed journals and feed composition tables. Although attempts were made to mainly include data that have been published since 1990, on a few occasions, it was necessary to include older data because of a lack of newer data for some of these ingredients. With the exception of ingredient tables, non-peer-reviewed literature was not used because of the uncertainty of the quality of this information.

\section{Copra meal and copra expellers}

The coconut palm (Cocos nucifera) is widely distributed throughout the tropics with major production in Indonesia, The Philippines, India, and in some African and Central American and South American countries. World production of copra meal and copra expellers is approximately 2,000,000 metric tons [1].

Copra meal is produced by expeller extracting or solvent extracting the oil from dried coconut kernels. Copra meal is sometimes referred to as coconut meal or coconut oil meal. Although its protein content is less than that of conventional ingredients commonly used as protein sources, copra meal represents the largest quantity of locally available feed protein in many tropical areas, such as countries in Central America, some African countries, and some countries in South East Asia. Variations in the nutrient composition of copra meal are mainly a function of the differences in residual oil concentration.
The residual oil in copra meal and copra expellers contains 50 to $70 \%$ medium-chain, saturated fatty acids (lauric acid and myristic acid), which can lead to firmer carcass fat when high levels of copra meal are used in the diet [3, 4]. Thus, the deposition of lauric acid and myristic acid is three to five times greater in the backfat of pigs fed $30 \%$ copra meal compared with pigs fed $10 \%$ copra meal [3]. Quality problems such as rancidity and aflatoxin contamination may be an issue in copra meal, which may cause reduced feed intake and in some cases reduced feed efficiency of pigs [5]. Quality problems may be attributed to the high moisture content of copra during drying and storage [6].

Copra meal and copra expellers contain between 10 and $16 \%$ crude fiber and approximately $47 \%$ total dietary fiber [7]. Concentrations of $\beta$-mannans, galactomannans, arabinoxylogalactans, and cellulose are relatively high $[8,9]$ and the water binding capacity of copra meal is much greater than that of palm kernel meal or palm kernel expellers [7]. Water binding capacity is an estimate of the amount of water that a fiber can absorb and hold after an external force has been applied to it via centrifugation. High water binding capacity will usually result in reduced feed intake of animals because of swelling in the intestinal tract. The relatively high concentrations of fermentable fiber in copra- and palm kernel ingredients may result in increased needs for dietary Thr because dietary fiber increases the endogenous losses of AA, and therefore increases the loss of Thr [9]. Protein levels of copra meal and copra expellers typically range from 20 to $26 \%$ (Table 1). The concentration of gross energy in copra meal is greater than in corn, but because of the high concentration of fiber in copra meal and copra expellers, concentrations of digestible energy (DE) and metabolizable energy (ME) are less than in corn $[10,11]$.

Copra meal and copra expellers contain between 0.50 and $0.58 \%$ total $\mathrm{P}[10,12,13]$, but less than one third of the $\mathrm{P}$ is bound to phytate. The standardized total tract digestibility (STTD) of $\mathrm{P}$, therefore, is relatively high in copra meal and copra expellers (Table 2; $[12,13]$ ). However, if microbial phytase is included in the diets, the STTD of P will increase [13].

The quality of the protein in copra meal is less than that of soybean meal and palm kernel products with Lys only being $1.91 \%$ of total crude protein $(\mathrm{CP})$ and total indispensable AA being $33.92 \%$ of total CP. However, one specific characteristic of copra protein is that it is high in Arg and Arg is almost $10 \%$ of total CP and the Arg:Lys ratio is almost 5:1 (Table 3).

The standardized ileal digestibility (SID) of AA in copra meal and copra expellers fed to pigs ranges between 43 and $81 \%$ [11, 14-16]. The SID of Lys in copra meal is also variable, ranging from $51[15,17]$ to $73 \%$ 
Table 1 Energy and nutrient composition and physical characteristics of copra and palm kernel ingredients (as-fed basis) ${ }^{1}$

\begin{tabular}{|c|c|c|c|c|c|}
\hline \multirow[b]{2}{*}{ Item $^{2}$} & \multirow[b]{2}{*}{ Copra meal } & \multicolumn{3}{|l|}{ Ingredient } & \multirow[b]{2}{*}{ Soybean mea } \\
\hline & & Copra expellers & Palm kernel expellers & Palm kernel meal & \\
\hline Dry matter, \% & 92.9 & 89.9 & 91.9 & 91.9 & 90.0 \\
\hline Bulk density, g/L & 502.4 & - & 634.1 & 401.0 & - \\
\hline Water binding capacity, g/g & 4.18 & - & 1.83 & 2.17 & - \\
\hline Gross energy, MJ/kg & 18.6 & 18.0 & 18.8 & 17.8 & 17.8 \\
\hline $\mathrm{DE}, \mathrm{MJ} / \mathrm{kg}$ & 14.4 & 15.8 & 12.1 & 11.3 & 15.2 \\
\hline $\mathrm{ME}, \mathrm{MJ} / \mathrm{kg}$ & 13.6 & 15.1 & 11.7 & 10.6 & 13.8 \\
\hline $\mathrm{NE}, \mathrm{MJ} / \mathrm{kg}$ & 7.3 & - & 8.1 & 6.9 & 8.7 \\
\hline Crude protein, $\%$ & 22.0 & 20.2 & 14.3 & 13.6 & 47.7 \\
\hline Acid hydrolyzed ether extract, \% & 1.9 & 7.1 & 6.9 & 1.3 & 2.9 \\
\hline Neutral detergent fiber, $\%$ & 54.8 & 54.4 & 70.6 & 77.9 & 8.2 \\
\hline Acid detergent fiber, \% & 26.9 & 29.6 & 43.0 & 49.4 & 5.3 \\
\hline Insoluble dietary fiber, \% & 41.4 & - & 60.9 & 68.7 & 16.7 \\
\hline Soluble dietary fiber, $\%$ & 5.5 & - & 2.6 & 2.2 & - \\
\hline Total dietary fiber, $\%$ & 46.9 & - & 63.5 & 70.9 & - \\
\hline
\end{tabular}

${ }^{1}$ References $[6,9,10,15]$

Table 2 Concentrations of minerals, phytate, and apparent total tract digestibility (ATTD) and standardized total tract digestibility (STTD) of phosphorus in copra and palm kernel ingredients (as-fed basis) ${ }^{1}$

\begin{tabular}{|c|c|c|c|c|c|}
\hline Item & Copra meal & Copra expellers & Palm kernel meal & Palm kernel expellers & Soybean meal \\
\hline $\mathrm{Ca}, \%$ & 0.04 & 0.11 & 0.20 & 0.25 & 0.33 \\
\hline $\mathrm{Cl}, \%$ & 0.37 & - & - & 0.15 & 0.05 \\
\hline$K, \%$ & 1.83 & 1.75 & - & 0.64 & 2.11 \\
\hline$M g, \%$ & 0.31 & 0.23 & - & 0.29 & 0.28 \\
\hline $\mathrm{Na}, \%$ & 0.04 & - & - & 0.03 & 0.05 \\
\hline$P, \%$ & 0.52 & 0.53 & 0.54 & 0.52 & 0.67 \\
\hline $\mathrm{S}, \%$ & 0.31 & - & - & 0.22 & 0.4 \\
\hline $\mathrm{Cu}, \mathrm{ppm}$ & 25 & 40 & - & 21 & 16.5 \\
\hline $\mathrm{Fe}, \mathrm{ppm}$ & 486 & - & - & 534 & 190.5 \\
\hline Mn, ppm & 69 & 75 & - & 131 & 36.7 \\
\hline Zn, ppm & 49 & 53 & - & 32 & 47.9 \\
\hline Phytate, \% & 0.79 & 0.78 & 1.12 & 1.29 & 1.55 \\
\hline Phytate P, \% & 0.22 & 0.22 & 0.32 & 0.35 & 0.44 \\
\hline Non-phytate P, \% & 0.30 & 0.31 & 0.22 & 0.16 & 0.23 \\
\hline \multicolumn{6}{|c|}{ P digestibility without phytase } \\
\hline ATTD, \% & 60.8 & 46.0 & 48.9 & 30.0 & 41.1 \\
\hline STTD, \% & 70.6 & 56.5 & 57.9 & 39.8 & 49.6 \\
\hline \multicolumn{6}{|c|}{ P digestibility with phytase } \\
\hline ATTD, \% & 80.8 & - & 64.1 & 58.2 & 72.2 \\
\hline STTD, \% & 90.3 & - & 73.5 & 68.1 & 81.1 \\
\hline
\end{tabular}

${ }^{1}$ References $[2,9,11,12,46]$ 
Table 3 Amino acid (AA) composition in copra and palm kernel ingredients (as-fed basis) ${ }^{1}$

\begin{tabular}{|c|c|c|c|c|c|c|c|c|c|c|}
\hline \multirow[t]{2}{*}{ Item } & \multicolumn{2}{|c|}{ Copra meal } & \multicolumn{2}{|c|}{ Copra expellers } & \multicolumn{2}{|c|}{ Palm kernel meal } & \multicolumn{2}{|c|}{ Palm kernel expellers } & \multicolumn{2}{|c|}{ Soybean meal } \\
\hline & $\%$ & $\%$ of $C P$ & $\%$ & $\%$ of $C P$ & $\%$ & $\%$ of $C P$ & $\%$ & $\%$ of $C P$ & $\%$ & $\%$ of $C P$ \\
\hline Crude protein & 22.00 & - & 20.20 & - & 13.60 & - & 14.30 & - & 47.73 & - \\
\hline \multicolumn{11}{|c|}{ Indispensable AA } \\
\hline Arg & 2.08 & 9.45 & 1.70 & 8.42 & 1.36 & 10.00 & 1.52 & 10.63 & 3.45 & 7.23 \\
\hline His & 0.35 & 1.59 & 0.29 & 1.44 & 0.17 & 1.25 & 0.20 & 1.40 & 1.28 & 2.68 \\
\hline Ile & 0.66 & 3.00 & 0.06 & 0.30 & 0.41 & 3.01 & 0.47 & 3.29 & 2.14 & 4.48 \\
\hline Leu & 1.20 & 5.45 & 1.19 & 5.89 & 0.71 & 5.22 & 0.82 & 5.73 & 3.62 & 7.58 \\
\hline Lys & 0.42 & 1.91 & 0.39 & 1.93 & 0.36 & 2.65 & 0.36 & 2.52 & 2.96 & 6.20 \\
\hline Met & 0.27 & 1.23 & 0.24 & 1.19 & 0.22 & 1.62 & 0.25 & 1.75 & 0.66 & 1.38 \\
\hline Phe & 0.79 & 3.59 & 0.79 & 3.91 & 0.47 & 3.46 & 0.53 & 3.71 & 2.40 & 5.03 \\
\hline Thr & 0.55 & 2.50 & 0.57 & 2.82 & 0.33 & 2.43 & 0.37 & 2.59 & 1.86 & 3.90 \\
\hline Trp & 0.15 & 0.68 & 0.15 & 0.74 & 0.05 & 0.37 & 0.12 & 0.84 & 0.66 & 1.38 \\
\hline Val & 0.97 & 4.41 & 0.91 & 4.50 & 0.57 & 4.19 & 0.65 & 4.55 & 2.23 & 4.67 \\
\hline Total & 7.44 & 33.81 & 6.29 & 31.14 & 4.65 & 34.20 & 5.29 & 37.01 & 21.26 & 44.53 \\
\hline \multicolumn{11}{|c|}{ Dispensable AA } \\
\hline Ala & 0.85 & 3.86 & 0.79 & 3.91 & 0.46 & 3.38 & 0.53 & 3.71 & 2.06 & 4.32 \\
\hline Asp & 1.50 & 6.82 & 1.49 & 7.38 & 0.89 & 6.54 & 0.99 & 6.92 & 5.41 & 11.33 \\
\hline Cys & 0.28 & 1.27 & 0.26 & 1.29 & 0.17 & 1.25 & 0.17 & 1.19 & 0.70 & 1.47 \\
\hline Glu & 3.34 & 15.18 & 3.43 & 16.98 & 2.02 & 14.85 & 2.29 & 16.01 & 8.54 & 17.89 \\
\hline Gly & 0.82 & 3.73 & 0.82 & 4.06 & 0.53 & 3.90 & 0.58 & 4.06 & 1.99 & 4.17 \\
\hline Pro & 0.60 & 2.73 & 0.63 & 3.12 & 0.36 & 2.65 & 0.40 & 2.80 & 2.53 & 5.30 \\
\hline Ser & 0.71 & 3.23 & 0.77 & 3.81 & 0.44 & 3.24 & 0.50 & 3.50 & 2.36 & 4.94 \\
\hline Tyr & 0.41 & 1.86 & 0.54 & 2.67 & 0.29 & 2.13 & 0.29 & 2.03 & 1.59 & 3.33 \\
\hline Total & 8.51 & 38.68 & 8.73 & 43.22 & 5.16 & 37.94 & 5.75 & 40.22 & 25.18 & 52.75 \\
\hline \multicolumn{11}{|l|}{ All AA } \\
\hline Arg:Lys, \% & 4.95 & - & 4.36 & - & 3.78 & - & 4.22 & - & 1.17 & - \\
\hline
\end{tabular}

${ }^{1}$ References $[9,10,15]$

[10], but the SID of all other indispensable AA is greater than that of Lys indicating that the sources of copra meal used in these experiments may have been heat damaged because heat damage will reduce the digestibility of Lys more than that of other AA [18-20]. The SID of Lys in copra expellers was reported at only $40 \%$ [16], which was much less than for other indispensable AA indicating that this source was also heat damaged. The differences in AA digestibility among experiments may also be due to differences in nutrient composition, drying procedures, oil extraction procedures, and the degree and duration of heat processing that is used during oil extraction [21]. Overall, the SID of protein and indispensable AA in copra expellers is less than in soybean meal, but similar to those in palm kernel meal (Table 4; [11]).

Copra meal and copra expellers may be included in diets fed to growing and finishing pigs by up to $30 \%$ without affecting growth performance [22], but negative effects of increasing levels of copra meal in the diet have been reported [4, 14, 23]. However, Thorne et al. [3] demonstrated that copra meal can be used by up to $50 \%$ in growing-finishing diets if diets are supplemented with synthetic AA or proteins with higher quality. Results with copra meal have been improved if diets either were semi-purified diets or if they were formulated based on digestible AA rather than based on crude protein [3].

In diets fed to weanling pigs from $2 \mathrm{wk}$ post-weaning, performance was linearly reduced if copra meal was included in the diet and pigs fed diets containing $15 \%$ copra meal gained approximately $1 \mathrm{~kg}$ less over a 3 -wk period than pigs fed a control diet without copra meal [7]. This result was obtained even though diets were balanced for digestible AA and ME. It is possible that it is the high fiber concentration and the high water binding capacity of the fiber in copra meal that resulted in the pigs eating less and therefore gaining less weight because of the increased gut fill that is associated with consuming diets with high water binding capacity. However, 
Table 4 Standardized ileal digestibility (\%) of amino acids (AA) in copra and palm kernel products and in soybean meal ${ }^{1}$

\begin{tabular}{|c|c|c|c|c|c|}
\hline Item & Copra meal & Copra expellers & Palm kernel meal & Palm kernel expellers & Soybean meal \\
\hline Crude protein & 79.9 & 67.6 & 71.3 & 81.8 & 87.0 \\
\hline \multicolumn{6}{|c|}{ Indispensable AA } \\
\hline $\operatorname{Arg}$ & 91.2 & 90.0 & 88.3 & 90.4 & 94.0 \\
\hline His & 82.5 & 73.2 & 80.8 & 83.6 & 90.0 \\
\hline Ile & 81.6 & 76.7 & 80.4 & 83.5 & 89.0 \\
\hline Leu & 81.6 & 78.5 & 79.7 & 82.4 & 88.0 \\
\hline Lys & 72.8 & 40.3 & 71.1 & 76.5 & 89.0 \\
\hline Met & 85.5 & 82.1 & 82.2 & 85.0 & 90.0 \\
\hline Phe & 84.5 & 81.4 & 82.2 & 84.6 & 88.0 \\
\hline Thr & 76.7 & 64.4 & 73.9 & 77.2 & 85.0 \\
\hline Trp & 88.4 & 66.3 & 87.5 & 89.4 & 91.0 \\
\hline Val & 79.0 & 77.8 & 77.2 & 81.0 & 87.0 \\
\hline Mean & 82.6 & 73.1 & 80.3 & 83.4 & 89.1 \\
\hline \multicolumn{6}{|l|}{ Dispensable AA } \\
\hline Ala & 78.2 & 79.0 & 72.5 & 79.0 & 85.0 \\
\hline Asp & 78.9 & 66.5 & 75.8 & 77.5 & 87.0 \\
\hline Cys & 68.0 & 53.1 & 71.7 & 76.4 & 84.0 \\
\hline Glu & 79.9 & 67.3 & 81.2 & 82.0 & 89.0 \\
\hline Gly & 76.2 & 60.6 & 65.1 & 77.9 & 84.0 \\
\hline Pro & 128.8 & 125.0 & 54.9 & 121.5 & 113.0 \\
\hline Ser & 82.0 & 70.5 & 80.0 & 83.7 & 89.0 \\
\hline Tyr & 82.8 & 58.0 & 80.1 & 82.7 & 88.0 \\
\hline Mean & 83.7 & 72.5 & 75.2 & 83.7 & 89.9 \\
\hline Mean all AA & 83.2 & 72.8 & 77.6 & 83.5 & 89.5 \\
\hline
\end{tabular}

${ }^{1}$ Refereces $[9,10,15]$

gain to feed ratio was also reduced over the 3-wk feeding period if copra meal was used. It is, therefore, recommended that less than $15 \%$ copra meal is used in diets fed to weanling pigs.

\section{Palm kernel meal and palm kernel expellers}

Global production of palm kernel meal and palm kernel expellers has increased from approximately 5 million metric tons in 2005 to almost 7 million metric tons in 2012 [1]. The reason for this increase is the increased demand for palm oil, which is often used in the biodiesel industry. Produced mainly in Southeast Asia and Africa, the oil palm fruit (Elaeis guineensis) yields palm oil extracted from the fleshy, outer mesocarp that surrounds the nut and palm kernel oil extracted from the kernel within the inner, hard shelled nut [24]. Prior to oil extraction, the outer shell of the kernel is cracked open, separated, and subjected to steam conditioning. Mechanical extraction by screw pressing is the most common process in oil extraction from palm kernels, which results in production of palm kernel expellers. However, sometimes oil is removed via solvent extraction, and the resultant co-product is called palm kernel meal.

The nutrient concentration of palm kernel meal and palm kernel expellers depends on the method of oil extraction, the species of the palm nut, and the amount of shell remaining in the meal [25]. Palm kernel expellers have a residual oil concentration of 6 to $8 \%$, whereas solvent-extracted meals contain 1 to $2 \%$ residual oil (Table 1; $[26,27])$. The concentration of crude fiber in palm kernel meal ranges between 7 and $20 \%$ [28], depending on the amount of shells and fruit removed from the palm kernel. More than $81 \%$ of the total carbohydrates in palm kernel meal are in the form of non-starch polysaccharides [29], mainly as $\beta$ - $(1,4)-D$-mannans [30, 31]. Palm kernel meal also contains high amounts of lignin, which may be a result of contamination of nut shells [32], which contributes to its grittiness and fibrous texture. However, water binding capacity in palm kernel meal and palm kernel expellers is less than in copra meal [7]. Because of the high concentration of insoluble dietary fiber, the energy in palm kernel meal and palm kernel expellers is poorly digested by pigs and 
concentrations of DE and ME in palm kernel meal and palm kernel expellers is less than $75 \%$ of that in soybean meal and corn (Table 1; $[10,11])$. However, energy digestibility in diets containing palm kernel expellers may be increased by 2 to 3 percentage units if betamannanase is added to the diet [32] because betamannanase may help digesting some of the D-mannans in palm kernel expellers.

The concentration of $\mathrm{P}$ in palm kernel meal and palm kernel expellers is between 0.5 and $0.65 \%$ [10, 12, 13]. However, between 60 and $75 \%$ of total $P$ is bound to phytate and the STTD of P in palm kernel meal and palm kernel expellers is, therefore, between 35 and $50 \%$ (Table 2; $[10,12,13]$ ). Because of the relatively high concentration of phytate in palm kernel products, the STTD of $\mathrm{P}$ can be increased to between 60 and $75 \%$ if microbial phytase is added to the diets[13]. As a consequence, the supply of digestible $\mathrm{P}$ from palm kernel meal and palm kernel expellers is similar to that of soybean meal if microbial phytase is added to the diet [13].

Relative to other oilseed meals, palm kernel meal has the lowest protein concentration ranging from 14 to $21 \%[11,26]$. Palm kernel protein has a low concentration of Trp and a relatively high concentration of Arg, which is approximately $10 \%$ of the CP (Table 3; [11, 33]). However, the Arg:Lys ratio is around 4:1 (Table 3) and as is the case with copra co-products, the supply of Arg is much greater than if other feed ingredients are used. The high concentration of Arg may suppress the digestibility of Lys because Arg and Lys compete for the same transporter in the enterocytes [34, 35]. However, making sure that diets are sufficient in digestible Lys may minimize the negative effect of high concentration of Arg. In general, the standardized ileal digestibility of AA in both palm kernel meal and palm kernel expellers is less than in soybean meal, but not different from copra meal (Table 4; [11, 36, 37]).

Palm kernel meal and palm kernel expellers are not always well-accepted by pigs [38, 39] and if included by more than $20 \%$ in the diet, palm kernel meal negatively affects growth performance and carcass quality of growing finishing pigs $[40,41]$. It is, however, possible that if diets are formulated to be equal in standardized ileal digestible indispensable AA, pigs will be able to perform better on diets containing palm kernel meal and palm kernel expellers. Finishing pigs have greater tolerance for palm kernel meal than nursery pigs [28]. In experiments with weanling pigs, it was observed that if diets are formulated to contain similar concentrations of digestible $\mathrm{AA}$ and $\mathrm{ME}$, feed conversion rates may be maintained if up to $15 \%$ palm kernel meal or palm kernel expellers are included in the diets [7]. However, average daily gain may be slightly reduced if palm kernel products are used, which may be a result of reduced bulk density of the diet and increased water binding capacity [7].

\section{Full fat rice bran and defatted rice bran}

The global production of rice (Oryza sativa) exceeds 700 million metric tons per year and rice is the most produced cereal grain in the world after maize and wheat [42]. Rice is produced primarily for human consumption and is the main carbohydrate source in human diets in many countries in the world. The largest rice producing countries are China and India followed by Indonesia, Vietnam, and Thailand [42]. Annual production of rice in the United States is around 9 million metric tons, but the United States is the $5^{\text {th }}$ largest exporter of rice after Thailand, India, Vietnam, and Pakistan.

The main objective of producing rice is to produce polished white rice that is used for human consumption. However, paddy rice contains approximately $20 \%$ hulls that mainly consist of lignin and silica, and therefore, has very low nutritional value [43]. As a consequence, rice has to be de-hulled before consumption. Removal of the hulls results in production of brown rice that contains the bran layers, the germ, and the endosperm. Further processing is needed to remove the bran layers and endosperm and this results in production of rice bran, which may be used for animal feeding. After the bran has been removed, rice goes through several polishing steps before the final product, polished rice, is produced [44]. On a quantitative basis, rice bran is approximately $10 \%$ of the total weight of paddy rice, which means that approximately 70 million metric tons of rice bran is produced annually and is available for animal feeding. There are other co-products produced from rice including brewers rice and rice mill feed, but these products are produced in much smaller quantities.

Rice bran includes the pericarp, the aleurone, and the subaleurone layers of rice, but depending on the type of milling, fractions of the endosperm may make up 20 to $25 \%$ of the bran product [45]. Rice bran, therefore, may contain up to $30 \%$ starch $[10,46]$. The concentration of ether extract in rice bran varies between 14 and $24 \%$ depending on the variety of rice that was grown and the type of milling used [10, 46, 47]. However, because of the high concentration of lipase in rice bran, the fat may quickly peroxidize and become rancid $[45,48]$. As a consequence, rice bran needs to be stabilized by use of heat treatment such as extrusion to deactivate the lipase and thus reduce the risk of oxidation [49]. Alternatively, the fat may be removed from rice bran using solvent extraction to produce defatted rice bran with a concentration of fat of 2 to $4 \%$. Therefore, both full fat rice bran and defatted rice bran are available for animal feeding. 
Table 5 Energy and nutrient composition of full fat rice bran and defatted rice bran (as-fed basis) ${ }^{1}$

\begin{tabular}{|c|c|c|}
\hline \multirow[b]{2}{*}{ Item } & \multicolumn{2}{|l|}{ Ingredient } \\
\hline & Full fat rice bran & Defatted rice bran \\
\hline Dry matter, \% & 91.60 & 91.35 \\
\hline Ash, \% & 14.80 & 11.51 \\
\hline Gross energy, MJ/kg & 19.98 & 16.98 \\
\hline Digestible energy, MJ/kg & 12.98 & 9.21 \\
\hline Metabolizable energy, MJ/kg & 12.55 & 8.71 \\
\hline Net energy, MJ/kg & 9.54 & 6.50 \\
\hline Crude protein, $\%$ & 15.11 & 17.30 \\
\hline Acid hydrolyzed ether extract, \% & 13.77 & 3.52 \\
\hline Starch, \% & 27.00 & 26.25 \\
\hline Neutral detergent fiber, \% & 26.28 & 23.56 \\
\hline Acid detergent fiber, \% & 11.87 & 11.31 \\
\hline \multicolumn{3}{|l|}{ Minerals } \\
\hline $\mathrm{Ca}, \%$ & 0.22 & 0.17 \\
\hline $\mathrm{Cl}, \%$ & 0.08 & 0.10 \\
\hline $\mathrm{K}, \%$ & 1.45 & 1.11 \\
\hline $\mathrm{Mg}, \%$ & 0.72 & 0.81 \\
\hline $\mathrm{Na}, \%$ & 0.04 & 0.02 \\
\hline$P, \%$ & 2.16 & 1.89 \\
\hline Phytate-P, \% & 1.74 & 1.61 \\
\hline Non-phytate P, \% & 0.42 & 0.28 \\
\hline S, \% & 0.18 & 0.15 \\
\hline $\mathrm{Cu}, \mathrm{ppm}$ & 8.00 & 14.00 \\
\hline $\mathrm{Fe}, \mathrm{ppm}$ & 113.00 & 268.00 \\
\hline Mn, ppm & 219.50 & 267.00 \\
\hline Zn, ppm & 45.70 & 73.00 \\
\hline ATTD ${ }^{2}$ of $P$ without phytase, $\%$ & 24.00 & 12.00 \\
\hline ATTD of P with phytase, $\%$ & 62.00 & - \\
\hline STTD ${ }^{3}$ of $P$ witout phytase, $\%$ & 36.50 & 28.00 \\
\hline STTD of P with phytase, $\%$ & 64.00 & - \\
\hline
\end{tabular}

${ }^{1}$ References [9, 42, 46, 59]

${ }^{2}$ ATTD, apparent total tract digestibility

${ }^{3}$ STTD, standardized total tract digestibility

Full fat rice bran contains 20 to $30 \%$ neutral detergent fiber and the concentration of $\mathrm{CP}$ is approximately $15 \%[10,46,47]$. Values for DE in full fat rice bran have been reported between 3,000 and 3,100 kcal per $\mathrm{kg}$ and values for ME are approximately $100 \mathrm{kcal}$ less than the DE values (Table 5; [10, 46]). Concentrations of neutral detergent fiber and CP in defatted rice bran are 10 to $15 \%$ greater than in full fat rice bran because removal of the fat concentrates other nutrients in the bran. However, DE and ME values in defatted rice bran are much less than in full fat rice bran and values between 2,100 and $2,200 \mathrm{kcal}$ per $\mathrm{kg}$ have been reported $[10,46]$.
The concentration of $\mathrm{P}$ is greater in rice bran than in most other plant ingredients and values between 1.6 and $2.2 \%$ have been reported [10, 46, 50]. Between 70 and $90 \%$ of the $\mathrm{P}$ is bound in phytate, and the STTD of $\mathrm{P}$ in rice bran, therefore, is relatively low (Table 5; $[50,51])$. However, addition of 1,000 units/kg of microbial phytase will increase the STTD of $\mathrm{P}$ in rice bran by 15 to $50 \%$ [51].

The biological value of rice protein is high and the standardized ileal digestibility of most AA in polished rice is greater than in most other cereal grains except wheat [52]. The protein in rice bran also has a relatively high concentration of Lys, Met, Trp, and Thr (Table 6). However, the SID of AA in both full fat and defatted rice bran is considerably less than in polished rice and for most indispensable AA, values between 70 and $85 \%$ have been reported (Table 6; $[10,47]$ ).

There are relatively few reports on effects of including rice bran in diets fed to weanling, growing, or finishing pigs. However, inclusion of $10 \%$ rice bran in diets fed to weanling pigs improved feed conversion rate by almost $10 \%$ because of increased colonic concentrations of bifidobacteria [53]. A balanced microbial community with a large presence of the beneficial bacteria is critical for weanling pigs to maintain their intestinal health. The prebiotic effect of rice bran was likely related to arabinoxylan oligosaccharides in this ingredient [54, 55]. However, it is not known what the maximum inclusion rate is. For growing and finishing pigs, reduced growth performance has been reported for inclusion of $30 \%$ full fat rice bran [56]. Inclusion of $10 \%$ full fat rice bran in

Table 6 Amino acid (AA) composition and standardized ileal digestibility (SID) of AA in full fat rice bran and defatted rice bran (as-fed basis) ${ }^{1}$

\begin{tabular}{|c|c|c|c|c|c|c|}
\hline \multirow[t]{2}{*}{ Item } & \multicolumn{3}{|c|}{ Full fat rice bran } & \multicolumn{3}{|c|}{ Defatted rice bran } \\
\hline & $\%$ & $\%$ of $C P$ & SID, \% & $\%$ & $\%$ of CP & $\mathrm{SID}, \%$ \\
\hline Crude protein & 14.80 & - & - & 16.27 & - & - \\
\hline \multicolumn{7}{|c|}{ Indispensable AA } \\
\hline Arg & 1.15 & 7.79 & 93.0 & 1.31 & 8.07 & 90.5 \\
\hline His & 0.38 & 2.59 & 87.8 & 0.45 & 2.74 & 82.7 \\
\hline \|le & 0.49 & 3.34 & 83.2 & 0.68 & 3.54 & 78.4 \\
\hline Leu & 0.98 & 6.66 & 82.9 & 1.15 & 7.06 & 77.7 \\
\hline Lys & 0.64 & 4.35 & 85.8 & 0.75 & 4.59 & 82.3 \\
\hline Met & 0.29 & 1.95 & 87.3 & 0.33 & 2.05 & 78.7 \\
\hline Phe & 0.62 & 4.18 & 81.1 & 0.72 & 4.40 & 78.0 \\
\hline Thr & 0.52 & 3.51 & 80.6 & 0.62 & 3.79 & 77.0 \\
\hline Trp & 0.18 & 1.19 & 83.0 & 0.21 & 1.27 & 79.7 \\
\hline Val & 0.75 & 5.04 & 83.9 & 0.87 & 5.35 & 79.0 \\
\hline Total & 6.00 & 40.54 & - & 7.09 & 43.58 & - \\
\hline
\end{tabular}

${ }^{1}$ Reference $[9,46,60]$ 
diets fed to growing pigs had no influence on the growth performance compared with pigs fed a corn-soybean meal control diet [50]. In finishing diets, inclusion of $20 \%$ full fat rice bran improved performance compared with pigs fed defatted rice bran [57], and it has been suggested that the maximum inclusion rate of defatted rice bran in diets fed to growing-finishing pigs is $20 \%$ [58]. It is, however, possible, that the reduced performance of pigs fed the defatted rice bran simply is an effect of the reduced metabolizable energy in the defatted rice bran. If that is the case then it is expected that the reduction in growth performance observed for pigs fed defatted rice bran can be avoided if diets are formulated to be isocaloric. However, to our knowledge, research to test this hypothesis has not been reported.

\section{Abbreviations}

AA: Amino acids; ATTD: Apparent total tract digestibility; CP: Crude protein; DM: Dry matter; DE: Digestible energy; ME: Metabolizable energy; SID: Standardized ileal digestibility; STTD: Standardized total tract digestibility.

\section{Competing interests}

The authors declare that they have no competing interest.

\section{Authors' contributions}

All authors equally contributed to this review. All authors read and approved the final manuscript.

\section{Acknowledgement}

This manuscript is based on papers presented at the $3^{\text {rd }}$ Chinese Swine Industry Symposium, Shanghai, China, Oct. 30 and 31, 2014; and the $28^{\text {th }}$ Annual PHILSAN Convention, Manila, Philippines, October 8, 2015

\section{Author details}

'Department of Animal Science, University of Illinois, Urbana 61801, USA. ${ }^{2}$ Departamento de Producción Animal, Facultad de Medicina Veterinaria y de Zootecnia, Universidad Nacional de Colombia, Bogotá, Colombia. ${ }^{3}$ University of California, Davis 95616, USA. "University of the Philippines, Los Baños, Philippines.

Received: 4 December 2015 Accepted: 8 December 2015

Published online: 23 December 2015

\section{References}

1. Soyatech. Soya and oilseed bluebook. Southwest Harbor: Soyatech LLC; 2012.

2. Creswell DC, Brooks CC. Compositions, apparent digestibility and energy evaluation of coconut oil and coconut meal. J Anim Sci. 1971;33:366-9.

3. Thorne PJ, Wiseman J, Cole DJA, Machin DH. Use of diets containing high levels of copra meal for growing/finishing pigs and their supplementation to improve animal performance. Trop Agric. 1988;65:197-201.

4. Thorne PJ, Wiseman J, Cole DJA, Machin D. Effects of level of inclusion of copra meal in balanced diets supplemented with synthetic amino acids on growth and fat deposition and composition in growing pigs fed ad libitum at a constant temperature of $25^{\circ} \mathrm{C}$. Anim Feed Sci Technol. 1992:40:31-40.

5. Schell TC, Lindemann MD, Kornegay ET, Blodgett DJ. Effects of feeding aflatoxin-contaminated diets with and without clay to weanling and growing pigs on performance, liver function, and mineral metabolism. J Anim Sci. 1993:71:1209-18.

6. Head SW, Swetman TA, Nagler MJ. Studies on deterioration and aflatoxin contamination in copra during storage. Oleagineux Corps Gras Lipides. 1999:6:349-59.

7. Jaworski NW, Shoulders J, González-Vega JC, Stein HH. Effects of using copra meal, palm kernel expellers, or palm kernel meal in diets for weanling pigs. Prof Anim Sci. 2014;30:243-51.

8. Balasubramaniam K. Polysaccharides of the kernel of maturing and matured coconuts. J Food Sci. 1976;41:1370-3.
9. Saittagaroon S, Kawakishi S, Namiki M. Characterisation of polysaccharides of copra meal. J Sci Food Agric. 1983;34:855-60.

10. NRC. Nutrient requirements of swine. 11th edition. Washington, DC: Natl Acad Press; 2012

11. Sulabo RC, Ju WS, Stein HH. Amino acid digestibility and concentration of digestible and metabolizable energy in copra meal, palm kernel expellers, and palm kernel meal fed to growing pigs. J Anim Sci. 2013;91:1391-9.

12. Son AR, Shin SY, Kim BG. Standardized total tract digestibility of phosphorus in copra expellers, palm kernel expellers, and cassava root fed to growing pigs. Asian-Australas J Anim Sci. 2013;26:1609-13.

13. Almaguer BL, Sulabo RC, Liu Y, Stein HH. Standardized total tract digestibility of phosphorus in copra meal, palm kernel expellers, palm kernel meal, and soybean meal fed to growing pigs. J Anim Sci. 2014;92:2473-80.

14. Lekule FP, Homb T, Kategile JA. Digestibility and effect of copra cake on rate of gain, feed efficiency and protein retention of fattening pigs. Trop Anim Health Prod. 1986;18:243-7.

15. Thorne PJ, Wiseman J, Cole DJA, Machin DH. Amino acid composition and aspects of protein quality in expeller copra meals for pig feeding. Trop Sci. 1992;32:145-51.

16. Son AR, Hyun Y, Htoo JK, Kim BG. Amino acid digestibility in copra expellers and palm kernel expellers by growing pigs. Anim Feed Sci Technol. 2014;187:91-7.

17. Thorne PJ, Wiseman J, Cole DJA, Machin DH. The digestible and metabolizable energy value of copra meals and their prediction from chemical composition. Anim Prod. 1989:49:459-66.

18. Gonzalez-Vega JC, Kim BG, Htoo JK, Lemme A, Stein HH. Amino acid digestibility in heated soybean meal fed to growing pigs. J Anim Sci. 2011:89:3617-25.

19. Almeida FN, Htoo JK, Thomson J, Stein HH. Amino acid digestibility in heat damaged distillers dried grains with solubles fed to pigs. J Anim Sci Biotech. 2013;4:44-54

20. Almeida FN, Htoo JK, Thomson J, Stein HH. Effects of balancing crystalline amino acids in diets containing heat-damaged soybean meal or distillers dried grains with solubles fed to weanling pigs. Animal. 2014;8:1594-602.

21. Samson AS. Heat treatment of coconut meats and coconut meal. J Sci Food Agric. 1971:22:312-6

22. Grieve GC, Osbourn DF, Gonzales FO. Coconut oil meal in growing and finishing rations for swine. Trop Agri Trinidad. 1966:43:257-61.

23. O'Doherty JV, McKeon MP. The use of expeller copra meal in grower and finisher pig diets. Livest Prod Sci. 2000;67:55-65.

24. Ravindran V, Blair R. Feed resources for poultry production in Asia and the Pacific. II. Plant protein sources. Worlds Poult Sci J. 1992;48:205-31.

25. O'Mara FP, Muligan FJ, Cronin EJ, Rath M, Caffrey PJ. The nutritive value of palm kernel meal measured in vivo and using rumen fluid and enzymatic techniques. Livest Prod Sci. 1999:60:305-16.

26. Nwokolo EN, Bragg DB, Saben HS. A nutritive evaluation of palm kernel meal for use in poultry rations. Trop Sci. 1977;19:147-54.

27. Onwudike OC. Palm kernel meal as a feed for poultry. 3. Replacement of groundnut cake by palm kernel meal in broiler diets. Anim Feed Sci Technol. 1986;16:195-202.

28. Babatunde GM, Fetuga BL, Odumosu O, Oyenuga VA. Palm kernel meal as the major protein concentrate in the diets of pigs in the tropics. J Sci Food Agric. 1975;26:1279-91.

29. Knudsen KEB. Carbohydrate and lignin contents of plant materials used in animal feeding. Anim Feed Sci Technol. 1997;67:319-38.

30. Daud MJ, Jarvis MC. Mannan of oil palm kernel. Phytochemistry. 1992:31:463-4.

31. Dusterhoft EM, Posthumus MA, Voragen AGJ. Non-starch polysaccharides from sunflower (Helianthus annuus) meal and palm kernel (Elaeis quineensis) meal preparation of cell wall material and extraction of polysaccharide fractions. J Sci Food Agric. 1992;59:151-60.

32. Mok CH, Lee JH, Kim BG. Effects of exogenous phytase and betamannanase on ileal and total tract digestibility of energy and nutrient in palm kernel expeller-containing diets fed to growing pigs. Anim Feed Sci Technol. 2013;186:209-13.

33. Owusu-Domfeh $\mathrm{K}$, Christensen DA, Owen BD. Nutritive value of some Ghanaian feedstuffs. Can J Anim Sci. 1970;50:1-14.

34. Closs El, Simon A, Vékony N, Rotmann A. Plasma membrane transporters for arginine. J Nutr. 2004;134:2752S-9S.

35. Verrey F, Closs El, Wagner CA, Palacin M, Endou H, Kanai Y. CATs and HATS: the SLC7 family of amino acid transporters. Pflugers Arch. 2004;447:532-42. 
36. Nwokolo EN, Bragg DB, Saben HS. The availability of amino acids from palm kernel, soybean, cotton seed and rape seed meal for the growing chick. Poult Sci. 1976;55:2300-4.

37. Février $C$, Lechevestrier $Y$, Lebreton $Y$, Jaguelin-Peyraud. Prediction of the standardized ileal true digestibility of amino acids from the chemical composition of oilseed meals in the growing pig. Anim Feed Sci Technol. 2001;90:103-15

38. Gohl B. Tropical feeds: feed information summaries and nutritive values, FAO Animal Production and Health Series No. 12. Rome: Food and Agriculture Organization of the United Nations; 1981.

39. Kim BG, Lee JH, Jung HJ, Han YK, Park KM, Han IK. Effect of partial replacement of soybean meal with palm kernel meal and copra meal with growth performance, nutrient digestibility and carcass characteristics of finishing pigs. Asian-Aust J Anim Sci. 2001;14:821-30.

40. McDonald P, Edwards RA, Greenhalgh JFG. Palm kernel meal in animal nutrition. 4th ed. Harlow, United Kingdom: Longman; 1988:462-63.

41. Rhule SWA. Growth rate and carcass characteristics of pigs fed on diets containing palm kernel cake. Anim Feed Sci Technol. 1996;61:167-72.

42. FAOSTATS. 2012. http://faostat3.fao.org/download/Q/QC/E Accessed 14 Aug 2013.

43. Delcuour JA, Hoseney RC. Principles of cereal science and technology. 3rd ed. St. Paul, MN, USA: AACC International, Inc; 2010:12.

44. Singh A, Das M, Bal S, Boinejee R. Rice Processing. In R. P. Ferreira-Guine Pm, Reis-Correa M. editors. Engineering aspects of cereals and cereal based products. Boca Raton, FL, USA: CRC Press; 2013:71-97.

45. Prakash J, Ramaswamy HS. Rice bran proteins: properties and food uses. Crit Rev Food Sci Nutr. 1996:36:537-52.

46. Sauvant D, Perez JM, Tran G. Tables of composition and nutritional value of feed materials: pig, poultry, sheep, goats, rabbits, horses, and fish. Wageningen, the Netherlands: Wageningen Academic Publishers; 2004.

47. Kaufmann C, Sauer WC, Cervantes M, Zhang Y, Rademacher JHM, Htoo JK. Amino acid and energy digestibility in different sources of rice bran for growing pigs. Can J Anim Sci. 2005;85:355-63.

48. McCaskill DR, Orthoefer FT. Storage stability of extrusion stabilized and parboiled rice bran. In: Marshall WE, JI Wadsworth, editors. Rice, science and technology. New York, NY, USA: Marcel Dekker, Inc; 1994:37-47.

49. Hargrove KL Jr. Processing and utilization of rice bran in the United States. In Marshall WE, JI Wadsworth, editors. Rice, science and technology. New York, NY, USA: Marcel Dekker, Inc; 1994:381-404.

50. Abelilla JJ. Standardized total tract digestibility of phosphorus in rice bran with and without phytase supplementation in swine diets, M. S Thesis. Los Baños: University of the Philippines; 2014.

51. Casas GA, Stein HH. Effects of microbial phytase on the apparent and standardized total tract digestibility of phosphorus in rice coproducts fed to growing pigs. J Anim Sci. 2015;93:3441-8.

52. Cervantes-Pahm SK, Liu Y, Stein HH. Digestible indispensable amino acid score (DIAAS) and digestible amino acids in eight cereal grains. Br J Nutr. 2014;111:1663-72.

53. Herfel T, Jacobi S, Lin X, Van Heugten E, Fellner V, Odle J. Stabilized rice bran improves weaning performance via a prebiotic mechanism. J Anim Sci. 2013:91:907-13.

54. Annison G, Moughan PJ, Thomas DV. Nutritive activity of soluble rice bran arabinoxylans in broiler diets. Br Poult Sci. 1995;36:479-88.

55. Grieshop CM, Flickinger EA, Fahey Jr GC. Oral administration of arabinogalactan affects immune status and fecal microbial populations in dogs. J Nutr. 2002;132:478-82.

56. De Campos RML, Hierro E, Ordoñez JA, Bertol TM, De la Hoz L. A note on partial replacement of maize with rice bran in the pig diet on meat and backfat fatty acids. J Anim Feed Sci. 2006;15:427-33.

57. Chae BJ, Lee SD. Rancid rice bran affects growth performance and pork quality in finishing pigs. Asian-Aust J Anim Sci. 2002;15:94-101.

58. Warren $B E$, Farrell DJ. The nutritive value of full-fat and defatted Australian rice bran. II. Growth studies with chickens, rats and pigs. Anim Feed Sci Technol. 1990;27:229-46.

59. Warren $B E$, Farrell DJ. The nutritive value of full-fat and defatted Australian rice bran. I. Chemical composition. Anim Feed Sci Technol. 1990;27:219-28.

60. Casas GA, Stein HH. Amino acid digestibility in rice co-products fed to growing pigs. Anim Feed Sci Technol. 2015;207:150-8.

\section{Submit your next manuscript to BioMed Central and we will help you at every step:}

- We accept pre-submission inquiries

- Our selector tool helps you to find the most relevant journal

- We provide round the clock customer support

- Convenient online submission

- Thorough peer review

- Inclusion in PubMed and all major indexing services

- Maximum visibility for your research

Submit your manuscript at www.biomedcentral.com/submit
Biomed Central 